\title{
PENGARUH PENAMBAHAN TANIN DAUN NANGKA (Artocarpus heterophyllus) TERHADAP NILAI BIOLOGIS DAUN KELOR (Moringa oleifera) DAN JERAMI KACANG HIJAU (Vigna radiata) SECARA IN VITRO
}

\section{THE EFFECTS OF TANNIN ADDITION FROM Artocarpus heterophyllus LEAVES ON IN VITRO BIOLOGICAL VALUE OF KELOR (Moringa oleifera) LEAVE AND GREEN MUNG BEAN (Vigna radiata) STRAW}

\author{
Teguh Wahyono ${ }^{1 *}$, Wahidin Teguh Sasongko', Mar'atus Sholihah ${ }^{2}$, dan Megga Ratnasari \\ Pikoli $^{2}$ \\ ${ }^{1}$ Pusat Aplikasi Isotop dan Radiasi, BATAN, Jakarta Selatan, 12070 \\ ${ }^{2}$ Fakultas Sains dan Teknologi, UIN Syarif Hidayatullah, Banten, 15412
}

Submitted: 8 September 2016, Accepted: 6 December 2016

\begin{abstract}
INTISARI
Nutrien daun kelor (Moringa oleifera) dan jerami kacang hijau (Vigna radiata) sebagai hijauan pakan ternak cukup berkualitas sehingga perlu diproteksi untuk meningkatkan efektivitas penggunaannya di dalam rumen. Daun nangka mengandung total tanin sebesar $7,08 \%$, sehingga potensial digunakan sebagai bahan untuk memproteksi bahan pakan sumber protein. Studi in vitro perlu dilakukan untuk mengevaluasi penggunaan tepung daun nangka untuk meningkatkan efektivitas penggunaan hijauan berupa daun kelor dan jerami kacang hijau. Tujuan dari studi yang dilakukan adalah untuk mengetahui pengaruh penambahan tepung daun nangka terhadap nilai biologis daun kelor dan jerami kacang hijau. Evaluasi produksi metana juga dilakukan untuk mengetahui efisiensi proses fermentasi. Perlakuan penelitian adalah: 1) jerami kacang hijau; 2) jerami kacang hijau $+0,7 \%$ daun nangka; 3 ) jerami kacang hijau $+1,4 \%$ daun nangka; 4 ) daun kelor; 5 ) daun kelor $+0,7 \%$ daun nangka; 6 ) daun kelor $+1,4 \%$ daun nangka. Penelitian ini menggunakan rancangan acak lengkap dengan pengulangan sebanyak tiga kali. Pengamatan dilakukan terhadap produksi gas total (inkubasi ke-0, 2, 4, 6, 8, 10, 12, dan 24 jam), konsentrasi gas metana (\%), karakteristik produksi gas dan karakteristik produk fermentasi rumen. Hasil penelitian menunjukkan bahwa penambahan tepung daun nangka tidak berpengaruh terhadap produksi gas total, produksi gas maksimum dan laju degradasi kedua jenis hijauan pakan. Penambahan 0,7 dan $1,4 \%$ tepung daun nangka dapat menurunkan konsentrasi gas metana daun kelor berturut-turut sebesar $4,93 \%$ dan $3,19 \%$. Penambahan tepung daun nangka juga mampu meningkatkan rasio $\mathrm{CO}_{2}: \mathrm{CH}_{4}$ substrat jerami kacang hijau masing-masing sebesar 4,42 dan 6,49\%. Tepung daun nangka juga tidak memberikan efek negatif terhadap produk fermentasi rumen $\left(\mathrm{pH}, \mathrm{NH}_{3}, \mathrm{VFA}\right.$ total, dan degradasi bahan organik).
\end{abstract}

(Kata kunci: In vitro, Daun kelor, Produksi gas total, Tepung daun nangka, Jerami kacang hijau)

\section{ABSTRACT}

Previous studies indicated kelor (Moringa oleifera) leaves and green mung beans (Vigna radiata) straws can provide good nutrient sources for ruminant. Protection of high quality nutrients from rumen microbe degradation might improve nutrient utilization for ruminants. Nutrient protection using tannins is aplicable methods to formulate rumen undegradable feed. Jackfruit (Artocarpus heterophyllus) leave contain $7.08 \%$ tannins, therefore it is potential to be used as tannin source to protect nutrient of feed, especially protein, in the rumen. The purpose of this study was to investigate the effects of tannin addition from jackfruit leaves on biological values of kelor leaves and green mung bean straws by in vitro trial. Methane production was also observed to determine the effects of jackfruit leaves addition on kelor leave and green mung bean straw. The treatments were: 1) green mung bean straw; 2) green mung bean straw $+0.7 \%$ jackfruit leaves meal; 3) green mung bean straws $+1.4 \%$ jackfruit leaves meal; 4) kelor leaves; 5 ) kelor leaves $+0.7 \%$ jackfruit leaves meal; and 6) kelor leaves $+1.4 \%$ jackfruit leaves meal. Experimental design was a completely randomized design with six treatments and three replications. Total gas production (0, 2, 4, 6, 8, 10, 12, and $24 \mathrm{~h}$ of incubation), methane concentration (\%), the characteristics of gas production and rumen fermentation products were measured. Results showed that there was no significant different among treatments on total gas production, maximum gas production and degradation rate. Additions of either 0.7 and $1.4 \%$ jackfruit leaves meal significantly reduced $(P<0.05)$ methane

\footnotetext{
* Korespondensi (corresponding author):

Telp. + 628564342 0641, E-mail: teguhwahyono@batan.go.id
} 
concentration (\%) of M. oleifera leaves fermentation by 4.93 and $3.19 \%$, respectively. Addition of either 0.7 and $1.4 \%$ jackfruit leaves meal also improved $(P<0.05) \mathrm{CO}_{2}: \mathrm{CH}_{4}$ ratioof green mung bean straws by 4.42 and 6.49 , respectively. There was no negative effect for rumen fermentation product $(\mathrm{pH}, \mathrm{NH} 3$, total VFA and organic matter degradability) after jackfruit leaves meal addition.

(Key words: In vitro, Jackfruit leaves, Kelor leaves, Total gas production, Green mung bean straw)

\section{Pendahuluan}

Indonesia adalah negara tropis yang menyimpan berbagai potensi sumber daya pakan lokal. Bahan pakan lokal tersebut sebenarnya memiliki potensi sebagai sumber pakan berkualitas. Permasalahan yang ada adalah perlu kajian dan penerapan yang tepat dalam aplikasi pada ternak khususnya ternak ruminansia. Sebagai contoh, bahan pakan yang mengandung sumber protein tinggi belum tentu efisien penggunaannya karena pengaruh fermentasi mikroba rumen. Dua bahan pakan yang potensial digunakan sebagai sumber protein adalah daun kelor (Moringa oleifera) dan jerami kacang hijau (Vigna radiate). Kedua bahan tersebut memiliki ketersediaan melimpah di daerah tropis dan mengandung nilai nutrisi yang baik. Daun Moringa oleifera dan jerami Vigna radiata mengandung protein kasar berturut turut sebesar 25,10\% (Makkar and Becker, 1996) dan $15,32 \%$ (Sudrajad dan Sarjana, 2011).

$M$. oleifera adalah sumber suplemen protein yang potensial bagi ruminansia. $M$. Oleifera mendukung sintesis protein mikroba karena dapat menyediakan sumber $\mathrm{N}$ yang siap difermentasi (Soliva et al., 2005). Kholif et al. (2015) melaporkan bahwa M. Oleifera dapat digunakan sebagai sumber protein dalam ransum kambing Anglo-Nubian. Tepung daun $M$. Oleifera dapat meningkatkan konsumsi pakan, fermentasi rumen, kecernaan pakan dan produksi susu. Sudrajad dan Sarjana (2011) melaporkan bahwa brangkasan kacang hijau berpotensi digunakan sebagai pakan ternak kambing dan domba. Hal tersebut karena ketersediaannya yang cukup melimpah dan dapat disimpan untuk digunakan dalam bentuk silase. Berbagai daerah di Indonesia sudah memanfaatkan jerami V.radiata sebagai pakan ternak ruminansia. Limbah pertanian ini merupakan hijauan pakan potensial yang mudah didapat (Pomolango et al., 2016; Samadi et al., 2010).

Sebagai hijauan pakan ternak yang berfungsi untuk suplai protein, daun $M$. oleifera dan jerami $V$. radiata perlu diproteksi dari degradasi di dalam rumen. Soliva et al. (2005) melaporkan bahwa daun M. oleifera tidak disarankan untuk sumber protein, jika tidak terproteksi dari fermentasi rumen. Kedua hijauan pakan ternak ini cukup potensial dan mudah didapat sehingga perlu diproteksi untuk meningkatkan efektifitas penggunaannya di dalam rumen. Protein yang melewati rumen akan didegradasi oleh mikroba rumen menjadi molekul yang lebih kecil berupa peptida, asam amino dan ammonia. Produk degradasi protein di dalam rumen ini akan digunakan untuk sintesis protein mikroba. Suplai protein yang hanya berasal dari mikroba belum dapat memenuhi kebutuhan nutrisi pada ruminansia. Hal tersebut menjadi dasar diperlukannya proteksi terhadap pakan sumber protein yang bersifat undegradable agar sampai pada usus halus (Ali et al., 2009). Berbagai perlakuan proteksi protein dapat dilakukan dengan menggunakan formaldehid (Dutta dan Agrawal, 2000), ikatan chelate dengan mineral (Haryanto, 2012) dan bahan organik berupa senyawa metabolit sekunder (tanin) (Bunglavan dan Dutta, 2013). Penggunaan formaldehid dan bahan kimia lain untuk proteksi protein tidak disarankan karena kurang ramah lingkungan bagi pertanian organik (Bunglavan dan Dutta, 2013). Alternatif terbaik adalah penggunaan tanin sebagai senyawa metabolit sekunder untuk melindungi hijauan pakan sumber protein dari degradasi rumen.

Daun nangka adalah sumber tanin yang potensial digunakan sebagai proteksi protein. Hal tersebut karena pohon nangka tumbuh subur di daerah tropis dan cukup familiar bagi para petani peternak. Sasongko et al. (2010) melaporkan bahwa kandungan total tanin dan tanin terkondensasi pada daun nangka adalah 7,08 dan $5,57 \%$. Kongmanila dan Ledin (2009) melaporkan bahwa daun nangka (daun + petiole) mengandung $130 \mathrm{~g} / \mathrm{kg}$ tanin terkondensasi. Studi in vitro perlu dilakukan untuk mengevaluasi penggunaan tepung daun nangka untuk meningkatkan efektifitas penggunaan hijauan berupa daun $M$. oleifera dan jerami $V$. radiata. Metode in vitro gas test 
digunakan untuk menguji pakan tunggal dan memiliki korelasi yang tinggi dengan uji in vivo (Menke et al., 1979; Getachew et al., 2000; Hamid et al., 2007). Tujuan dari studi yang dilakukan adalah untuk mengevaluasi penambahan tepung daun nangka terhadap proses fermentasi dan degradasi daun $M$. oleifera dan jerami $V$. radiata. Evaluasi produksi metana juga dilakukan untuk mengetahui efektifitas fermentasi pada kedua hijauan pakan tersebut.

\section{Materi dan Metode}

\section{Persiapan bahan}

Daun $M$. oleifera $\mathrm{sp}$, jerami vigna radiata dan daun nangka dikeringkan pada suhu $60^{\circ} \mathrm{C}$ selama tiga hari kemudian digiling sampai halus. Sampel pakan dianalisis untuk mengetahui kadar bahan kering (BK), abu, protein kasar (PK), serat kasar (SK) dan lemak kasar (LK) (AOAC, 2010). Neutral detergent fiber (NDF) dan acid detergent fiber (ADF) juga dianalisis menggunakan prosedur dalam Goering dan Van Soest (1970). Cairan rumen yang digunakan selama penelitian berasal dari kerbau rawa berfistula.

\section{Prosedur evaluasi in vitro}

Sampel sebanyak $380 \mathrm{mg}$ ditimbang dan dimasukkan ke dalam syringe kaca volume $100 \mathrm{ml}$ (model Fortuna, Jerman). Koleksi cairan rumen diambil dari kerbau rawa berfistula sebelum pemberian pakan pada pagi hari. Ransum kerbau yang digunakan adalah kombinasi hijauan dan konsentrat (50:50). Cairan rumen disaring menggunakan kain kassa empat lipatan. Syringe kaca yang telah berisi sampel, diinkubasi terlebih dahulu pada suhu $39^{\circ} \mathrm{C}$ sebelum diisi cairan rumen-buffer. Prosedur inkubasi in vitro menggunakan metode Menke et al. (1979) yang dimodifikasi Blümmel et al. (1997). Inkubasi dilakukan pada suhu $39^{\circ} \mathrm{C}$ selama 24 jam. Replikasi sampel sebanyak tiga ulangan. Pengamatan produksi gas total dilakukan pada jam ke- 0 , 2, 4, 6, 8, 10, 12 dan 24. Pengukuran $\mathrm{pH}$, $\mathrm{NH}_{3}$, VFA total, populasi protozoa dan degradasi bahan organik (DBO) juga dilakukan pada sampel beserta cairan rumen-buffer yang telah diinkubasi selama 24 jam.

\section{Metode eksperimen dan analisis data}

Penelitian ini menggunakan rancangan acak lengkap. Setiap perlakuan dilakukan pengulangan sebanyak tiga kali. Perlakuan penelitian adalah: jerami $V$. radiate, jerami $V$. radiata $+0.7 \%$ daun nangka, jerami $V$. radiata $+1.4 \%$ daun nangka, daun $M$. Oleifera, daun $M$. oleifera $+0.7 \%$ daun nangka, dan daun $M$. oleifera $+1.4 \%$ daun nangka.

Pengaruh perlakuan dianalisa menggunakan bantuan perangkat SPSS 16.00 dilanjutkan dengan uji Duncan's Multiple Range Test (DMRT) (Steel dan Torrie, 1980) untuk melihat perbedaan antar perlakuan. Koleksi gas total, pengukuran konsentrasi gas metana, $\mathrm{CO}_{2}$, dan analisis inokulum sampel dilakukan setelah 24 jam inkubasi. Pengukuran konsentrasi metana dan $\mathrm{CO}_{2}$ menggunakan MRU gas analyzer. Pengukuran $\mathrm{pH}$ menggunakan $\mathrm{pH}$ meter Hanna instrument, pengukuran $\mathrm{NH}_{3}$ menggunakan metode mikrodifusi Conway (Conway, 1950), pengukuran VFA total berdasar metode AOAC (2010) sedangkan pengukuran protozoa menggunakan metode Ogimoto dan Imai (1981). Degradasi bahan organik diperoleh berdasarkan persamaan hasil eksperimen Menke et al. (1979) (Jayanegara dan Sofyan, 2009):

$$
\begin{gathered}
\text { DBO }(\%) \\
0.45 \mathrm{CP}+0.0651 \mathrm{Ash}
\end{gathered}=4.88+0.889 \mathrm{GP}+
$$

Di mana DBO: degradasi bahan organik; GP: produksi gas total selama 24 jam; PK: kandungan protein kasar sampel dan Ash adalah kandungan abu sampel.

Kinetika gas juga diukur menggunakan model eksponensial Orskov dan McDonald (1979) $p=a+b\left(1-e^{-c t}\right)$. Konstanta a dan b berturut turut adalah fraksi mudah larut dan fraksi tidak larut tetapi dapat terdegradasi. Konstanta c adalah laju kelarutan fraksi secara konstan per t satuan waktu. Kalkulasi fraksi a, b dan c menggunakan perangkat lunak fitcurve Neway®.

\section{Hasil dan Pembahasan}

\section{Produksi gas total}

Pola kenaikan produksi gas total dari kedua jenis hijauan yang difermentasi selama 24 jam dapat dilihat pada Gambar 1. Laju produksi gas total pada semua perlakuan semakin menurun antar titik pengukuran atau waktu inkubasi. Penurunan ini disebabkan oleh berkurangnya ketersediaan substrat seiring meningkatnya waktu inkubasi. Berkurangnya jumlah substrat yang dapat difermentasi akan berakibat pada penurunan produksi gas yang 
merupakan hasil fermentasi (Jayanegara dan Sofyan, 2008). Pada Gambar 1 juga terlihat produksi gas total sampel jerami $V$. radiata selalu menghasilkan nilai yang lebih tinggi dibandingkan daun $M$. oleifera. Hasil analisis statistik menunjukkan bahwa penambahan tepung daun nangka tidak memberikan pengaruh yang nyata pada produksi gas total kedua sampel hijauan.

Produksi gas total ketiga perlakuan jerami $V$. radiata selalu lebih tinggi dibandingkan ketiga perlakuan daun $M$. oleifera. Hal tersebut diduga disebabkan oleh perbedaan karakteristik kecepatan degradasi dari kedua sumber hijauan. Perbedaan ini berpengaruh pada adaptasi mikroba rumen dalam mendegradasi substrat pakan. Sofyan et al. (2015) melaporkan bahwa mikroba rumen membutuhkan waktu adaptasi (lag phase) sebelum mendegradasi substrat pakan yang tidak mudah larut. Tingginya produksi gas pada substrat pakan jerami $V$. radiata juga dapat disebabkan oleh kandungan fraksi NDF yang lebih rendah dibandingkan daun $M$. oleifera (Tabel 1). Fraksi NDF terdiri dari golongan lignin,

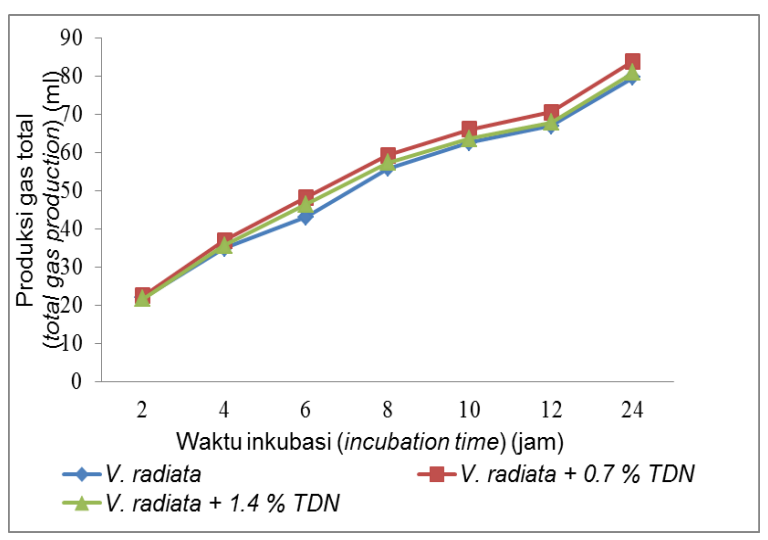

selulosa dan hemiselulosa yang cenderung sulit untuk didegradasi. Suprapto et al. (2013) dan Wahyuni et al. (2014) melaporkan bahwa tingginya komponen serat kasar berupa selulosa dan lignin dapat mempengaruhi rendahnya kecepatan degradasi pakan yang direpresentasikan pada rendahnya produksi gas.

Pemberian 0,7 dan $1,4 \%$ tepung daun nangka tidak berpengaruh terhadap produksi gas perlakuan jerami V.radiata maupun daun M. oleifera. Hal tersebut berbeda dengan penelitian Serensinhe et al. (2012) yang menjelaskan bahwa suplementasi tanin terkondensasi dapat menurunkan laju fermentasi hijauan yang diindikasikan oleh rendahnya produksi gas total. Jayanegara et al. (2009a) juga menjelaskan bahwa penambahan tannin dari ekstrak mimosa dan quebracho pada konsentrasi rendah $(0,5$ $\mathrm{mg} / \mathrm{ml}$ cairan rumen-buffer) dapat menurunkan produksi gas total pada substrat ransum berbasis hay. Kedua referensi tersebut menjelaskan bahwa penurunan produksi gas total disebabkan oleh pengaruh tanin dalam menghambat aktifitas/kinerja

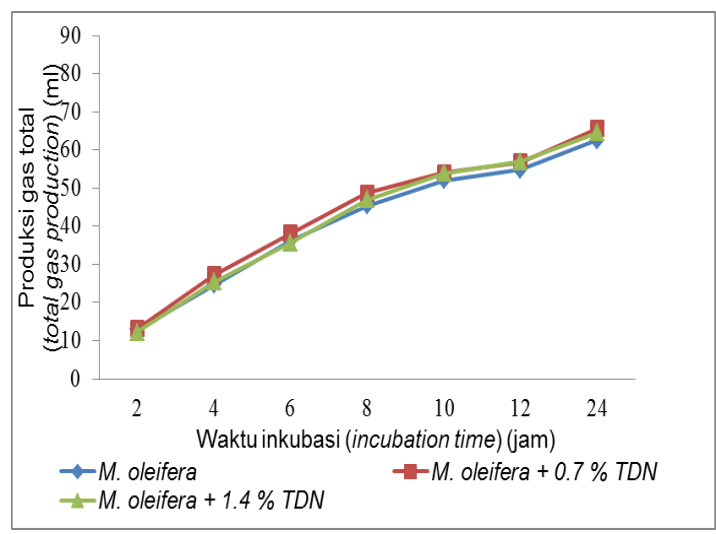

Gambar 1. Produksi gas total hasil fermentasi rumen secara in vitro pada jerami $V$. radiata dan daun $M$. oleifera yang ditambahkan tepung daun nangka

(total gas production after in vitro rumen fermentation of $V$. radiata straws and $M$. oleifera leaves with jackfruit leaves addition). Keterangan: tepung daun nangka (jackfruit leaves meal) (TDN).

Tabel 1. Kandungan nutrisi jerami $V$. radiata, daun $M$. oleifera dan tepung daun nangka (nutrient composition of $V$. radiata straw, M. oleifera leaveand Jackfruit leave meal)

\begin{tabular}{|c|c|c|c|c|c|c|}
\hline \multirow{2}{*}{$\begin{array}{c}\text { Bahan pakan } \\
\text { (feed materials) }\end{array}$} & \multicolumn{6}{|c|}{ Kandungan nutrisi (\%) (nutrient composition (\%)) } \\
\hline & $\begin{array}{l}\text { Bahan kering } \\
\text { (dry matter) }\end{array}$ & $\begin{array}{l}\text { Abu } \\
\text { (ash) }\end{array}$ & $\begin{array}{l}\text { Protein kasar } \\
\text { (crude protein) }\end{array}$ & $\begin{array}{l}\text { Lemak kasar } \\
\text { (ether extract) }\end{array}$ & NDF & ADF \\
\hline $\begin{array}{l}\text { Jerami } V . \text { radiate } \\
\text { (V. radiata straws) }\end{array}$ & 89,21 & 12,37 & 14,08 & 5,07 & 31,15 & 11,84 \\
\hline $\begin{array}{l}\text { Daun M. oleifera } \\
\text { (M. oleifera leaves) }\end{array}$ & 88,56 & 13,11 & 29,36 & 4,15 & 39,54 & 10,26 \\
\hline $\begin{array}{l}\text { Tepung daun nangka } \\
\text { (Jackfruit leaves meal) }\end{array}$ & 92,10 & 7,19 & 12,92 & 2,23 & 64,03 & 47,46 \\
\hline
\end{tabular}

NDF: neutral detergent fiber; ADF: acid detergent fiber. 
enzim yang dihasilkan mikroba. Hasil yang diperoleh dalam penelitian ini berbeda dengan referensi di atas. Perbedaan hasil ini disebabkan oleh perbedaan sumber tanin yang digunakan, di mana pada penelitian ini menggunakan tepung daun nangka yang belum diekstrak taninnya. Penggunaan tanin yang masih terikat dalam fraksi lain di dalam sumber hijauan belum mampu menghambat kinerja mikroba dalam mendegradasi pakan yang direpresentasikan dalam produksi gas total. Adapaun faktor lain yang perlu dipertimbangkan adalah konsentrasi masingmasing gas hasil fermentasi substrat pakan. Peubah tersebut dikaji pada bahasan selanjutnya pada konsentrasi gas metana (gambar 2) dan karakteristik produksi gas (Tabel 2).

\section{Konsentrasi gas metana (\%)}

Hasil pengukuran konsentrasi metana pada inkubasi sampel selama 24 jam dapat dilihat pada Gambar 2. Semakin tinggi produksi gas total maka semakin tinggi pula produksi gas metana di dalamnya. Atas dasar hal tersebut maka untuk mengukur produksi gas metana, maka perlu diketahui konsentrasi gas metana dalam setiap produksi gas total. Berdasarkan Gambar 2 dapat dilihat bahwa penambahan tepung daun nangka tidak berpengaruh terhadap konsentrasi gas metana pada jerami $V$. radiata. Hasil yang berbeda ditampilkan pada konsentrasi gas metana daun $M$. oleifera. Penambahan tepung daun nangka dapat menurunkan konsentrasi gas metana sebesar $4,93 \%$ dan $3,19 \%$ berturut-turut pada dosis tepung daun nangka 0,7 dan $1,4 \% \quad(P<0,05)$. Widiawati et al. (2010) melaporkan bahwa penurunan produksi gas metana dapat mengurangi kehilangan energi pakan yang terbuang, sehingga efisiensi penggunaan pakan akan semakin meningkat.

Konsentrasi gas metana pada substrat pakan jerami $V$. radiata terlihat lebih tinggi dibandingkan perlakuan daun M. oleifera. Hal tersebut sebanding dengan karakteristik produksi gas total yang ditampilkan pada Gambar 1. Tingginya kecepatan degradasi pakan juga berpengaruh terhadap proses pembentukan gas metana. Faktor lain yang berpengaruh adalah kandungan ADF jerami $V$. radiata lebih tinggi dibandingkan daun $M$. oleifera (Tabel 1). pada fraksi ADF terdapat golongan karbohidrat struktural berupa selulosa yang merupakan sumber energi utama bagi mikroba rumen. Widiawati et al. (2010) menjelaskan bahwa selulosa merupakan karbohidrat struktural yang terdapat pada dinding sel, fraksi tersebut merupakan sumber $C$ bagi mikroba rumen yang mengarah pada pembentukan VFA parsial berupa asam asetat. Dalam pembentukan asetat akan melepaskan fraksi $\mathrm{H}_{2}$ yang berafiliasi dengan $\mathrm{CO}_{2}$ sehingga berperan dalam pembentukan metana. Suharyono dan Widiawati (2007) juga menjelaskan bahwa tingginya produksi dan konsentrasi gas metana mengindikasikan besarnya energi pakan yang terbuang sehingga menurunkan efisiensi pakan. Hasil penelitian ini sesuai dengan pendapat Widiawati et al. (2010) yang melaporkan bahwa tanaman berkualitas baik dan mengandung protein yang lebih tinggi akan lebih sedikit menghasilkan gas metana dibandingkan pakan yang banyak mengandung serat atau sulit dicerna.

Tabel 2. Karakteristik gas hasil fermentasi rumen secara in vitro pada jerami $V$. radiata dan daun M. oleifera yang ditambahkan tepung daun nangka

(gas characteristics after in vitro rumen fermentation of $V$. radiata straw and $M$. oleifera leave with jackfruit leave addition)

\begin{tabular}{lcccccc}
\hline \hline $\begin{array}{l}\text { Sampel } \\
\text { (sample) }\end{array}$ & $\begin{array}{c}\text { Tepung daun nangka (\%) } \\
\text { (Jackfruit leaves meal (\%) }\end{array}$ & $\mathrm{a}+\mathrm{b}$ & $\mathrm{C}$ & $\begin{array}{c}\mathrm{CO}_{2} \\
(\mathrm{ml} / 100 \mathrm{mg} \\
\mathrm{DBO})\end{array}$ & $\begin{array}{c}\mathrm{CH}_{4} \\
(\mathrm{ml} / 100 \mathrm{mg} \\
\mathrm{DBO})\end{array}$ & $\begin{array}{c}\text { Rasio } \\
(\text { ratio) }\end{array}$ \\
\hline $\begin{array}{l}\mathrm{CO}_{2}: \mathrm{CH}_{4} \\
\text { V. radiata }\end{array}$ & 0 & $84,72^{\mathrm{a}}$ & $0,127^{\mathrm{b}}$ & $18,53^{\mathrm{bc}}$ & $5,46^{\mathrm{a}}$ & $3,39^{\mathrm{d}}$ \\
V. radiata & 0,7 & $87,60^{\mathrm{a}}$ & $0,136^{\mathrm{b}}$ & $19,55^{\mathrm{a}}$ & $5,53^{\mathrm{a}}$ & $3,54^{\mathrm{c}}$ \\
V. radiata & 1,4 & $84,41^{\mathrm{a}}$ & $0,136^{\mathrm{b}}$ & $18,91^{\mathrm{ab}}$ & $5,28^{\mathrm{a}}$ & $3,61^{\mathrm{bc}}$ \\
M. oleifera & 0 & $64,75^{\mathrm{b}}$ & $0,164^{\mathrm{a}}$ & $17,63^{\mathrm{cd}}$ & $4,77^{\mathrm{b}}$ & $3,70^{\mathrm{ab}}$ \\
M. oleifera & 0,7 & $67,38^{\mathrm{b}}$ & $0,170^{\mathrm{a}}$ & $17,11^{\mathrm{d}}$ & $4,49^{\mathrm{b}}$ & $3,82^{\mathrm{ab}}$ \\
M. oleifera & 1,4 & $67,14^{\mathrm{b}}$ & $0,166^{\mathrm{a}}$ & $17,40^{\mathrm{d}}$ & $4,43^{\mathrm{b}}$ & $3,93^{\mathrm{a}}$ \\
SEM & & 2,041 & 0,004 & 0,212 & 0,102 & 0,054 \\
\hline
\end{tabular}

$\mathrm{a}+\mathrm{b}$ (produksi gas maksimum); c (laju kelarutan fraksi per t satuan waktu); $\mathrm{CO}_{2}$ (karbon dioksida); $\mathrm{CH}_{4}$ (metana); $\mathrm{SEM}$ (standard error mean).

a,b,c,d Superskrip yang berbeda pada baris yang sama menunjukkan perbedaan yang nyata $(P<0,05)($ different supercsripts at the same row indicate significant differences $(P<0.05)$ ). 

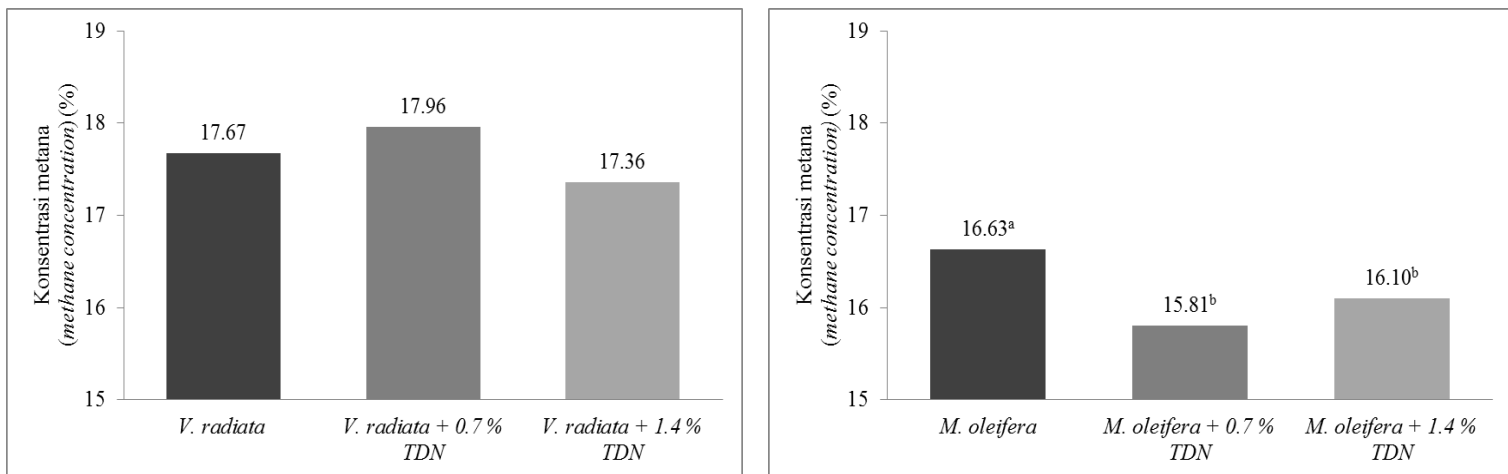

Gambar 2. Konsentrasi gas metana hasil fermentasi rumen secara in vitro pada jerami $V$. radiata dan daun $M$. oleifera yang ditambahkan tepung daun nangka

(methane concentration after in vitro rumen fermentation of $V$. radiata straws and M. oleifera leaves with jackfruit leaves addition. Keterangan: tepung daun nangka (jackfruit leaves meal) (TDN).

Penambahan tepung daun nangka terhadap konsentrasi gas metana memberikan pengaruh yang berbeda antara kedua perlakuan substrat pakan. Hal tersebut dapat dipengaruhi oleh perbedaan interaksi senyawa tanin yang terkandung dalam tepung daun nangka dengan kedua substrat. Interaksi yang dimaksud adalah interaksi dengan protein pakan serta mikroba rumen terutama protozoa. Tavendale et al. (2005) cit. Jayanegara et al. (2009b) menjelaskan bahwa terdapat dua mekanisme penghambatan produksi gas metana yaitu: 1) penghambatan pencernaan serat sehingga mengurangi produksi $\mathrm{H}_{2}$ dan 2) penghambatan pertumbuhan dan aktifitas metanogen. Karakteristik tanin tertinggi yang terdapat dalam daun nangka adalah jenis tanin terkondensasi $(5,57 \%)$ (Sasongko et al., 2010) yang menurunkan produksi gas metana dengan mekanisme yang pertama. Perbedaan interaksi tanin pada daun nangka diduga disebabkan oleh perbedaan karakteristik serat dalam substrat pakan. Kandungan serat yang sulit terdegradasi banyak terdapat pada jerami $V$. radiata dibandingkan daun $M$. oleifera. Hal tersebut direpresentasikan pada kandungan ADF (Tabel 1) sehingga penurunan gas metana akibat pemberian tepung daun nangka lebih nyata terlihat pada substrat daun $M$. oleifera.

Kadar total tanin pada daun nangka adalah $7,08 \%$ sehingga tetap ada proses mekanisme yang kedua dalam penurunan produksi gas metana. Jayanegara et al. (2015) dan Animut et al. (2008) menjelaskan bahwa senyawa tanin dapat menurunkan populasi aktor utama dalam proses metanogenesis di dalam rumen yaitu protozoa. Produksi gas metana memiliki relasi kuat dengan populasi protozoa. Gas metana diproduksi oleh bakteri archaea yang mengkonsumsi hidrogen. Bakteri ini bersimbiosis dengan protozoa. Namun demikian, mekanisme tannin terkondensasi dalam proses pembentukan metana belum dijelaskan secara rinci. Tanin secara langsung akan menurunkan pertumbuhan populasi mikroba metanogen atau secara tidak langsung menurunkan ketersediaan nutrien bagi mikroba rumen (Bhatta et al., 2015). Data penurunan populasi protozoa pada penelitian ini akibat pemberian tepung daun nangka dapat dilihat pada Tabel 3 .

Hasil penelitian ini sesuai dengan penelitian Sasongko et al. (2016) yang melaporkan bahwa pemberian $0,7 \%$ tepung daun nangka dapat menurunkan produksi gas metana pada substrat kacang hijau afkir. Pemberian $1,4 \%$ tepung daun nangka juga dapat menurunkan konsentrasi gas metana namun tidak berbeda nyata dengan pemberian pada taraf $0,7 \%$ (Gambar 2). Hal tersebut dapat disebabkan oleh tingkat kejenuhan penambahan tanin dalam mengikat protein pakan. Sasongko et al. (2010) menjelaskan bahwa penambahan tanin yang terlalu banyak akan menimbulkan kejenuhan, sehingga kemampuan untuk mengikat protein menjadi lebih sedikit.

\section{Karakteristik produksi gas}

Karakteristik produksi gas kedua hijauan pakan yang diberi tambahan tepung daun nangka dapat dilihat pada Tabel 2 . Produksi gas maksimum $(a+b)$ pada semua perlakuan jerami V.radiata lebih tinggi dibandingkan daun $M$. oleifera $(P<0.05)$, sedangkan penambahan tepung daun nangka tidak berpengaruh pada masing- 
masing substrat hijauan. Pola yang sama terjadi pada peubah laju kelarutan (c) dan produksi metana (ml/100 $\mathrm{mg}$ DBO). Penambahan $0,7 \%$ tepung daun nangka dapat meningkatkan produksi gas $\mathrm{CO}_{2}$ jerami V. radiata sebesar $5,50 \% \quad(\mathrm{P}<0,05)$, sedangkan penambahan $1,4 \%$ tidak memberikan pengaruh nyata. Pemberian 0,7 dan $1,4 \%$ tepung daun nangka juga mampu meningkatkan rasio $\mathrm{CO}_{2}: \mathrm{CH}_{4}$ substrat jerami $V$. radiata masing-masing sebesar 4,42 dan $6,49 \% \quad(P<0,05)$. Pola berbeda ditunjukkan pada substrat daun $M$. oleifera, dimana penambahan tepung daun nangka tidak berpengaruh nyata terhadap produksi gas $\mathrm{CO}_{2}$ dan rasio $\mathrm{CO}_{2}: \mathrm{CH}_{4}$.

Parameter karakteristik produksi gas merupakan indikator evaluasi fermentabilitas dari pengujian pakan secara in vitro (Sofyan et al., 2015). Produksi gas total maksimum adalah total produksi gas yang dihasilkan dari gabungan fraksi a dan b yaitu fraksi bahan yang mudah larut serta fraksi bahan yang dapat didegradasi mikroba rumen. Produksi gas total maksimum $(a+b)$ pada perlakuan jerami V.radiata lebih tinggi dibandingkan perlakuan daun M.oleifera. Penjelasan akan hal ini telah dibahas pada parameter produksi gas total, dimana kandungan fraksi NDF jerami V.radiata yang lebih rendah dibandingkan daun $M$. oleifera (Tabel 1). Kandungan NDF rendah berpengaruh pada degradasi substrat yang semakin cepat sehingga produksi gas maksimum akan lebih tinggi selama 24 jam inkubasi. Hal tersebut diperkuat dengan nilai laju degradasi (c) yang semakin cepat pada ketiga perlakuan jerami V.radiata. tepung daun nangka terbukti tidak berpegaruh terhadap produksi gas maksimum dan laju degradasi namun pengaruhnya terlihat pada komposisi gas total di dalamnya.

Pola menarik diperlihatkan pada peubah produksi gas $\mathrm{CO}_{2}$, metana dan rasio kedua gas tersebut. Penambahan tepung daun nangka tidak mempengaruhi produksi gas metana (ml/100 mg DBO) kedua substrat bahan pakan. Hal tersebut berbeda dengan pembahasan pada peubah konsentrasi gas metana (Gambar 2) dimana penambahan tepung daun nangka berpengaruh terhadap penurunan konsentrasi gas metana. Hal tersebut karena adanya perhitungan efisiensi fermentasi substrat setelah dikalkulasikan dengan nilai DBO (Tabel 3). Pola berbeda ditunjukkan pada peubah produksi gas $\mathrm{CO}_{2}$ (ml/100 mg DBO), di mana penambahan tepung daun nangka dapat meningkatkan produksi gas $\mathrm{CO}_{2}$ pada substrat jerami $V$. radiata. Hal tersebut menyebabkan kenaikan rasio gas $\mathrm{CO}_{2}: \mathrm{CH}_{4}$ yang merepresentasikan peningkatan efisiensi substrat pakan. Peningkatan efisiensi substrat pakan ini berasal dari mekanisme efek tanin pada tepung daun nangka dalam mempengaruhi kinerja protozoa dan bakteri metanogen. Penurunan populasi keduanya dapat menurunkan pemakaian gas $\mathrm{CO}_{2}$ yang digunakan sebagai komponen pembentukan gas metana. Bhatta et al. (2007) menjelaskan bahwa komponen utama proses metanogenesis pada ruminansia adalah ion hidrogen dan $\mathrm{CO}_{2}$.

Penambahan tepung daun nangka tidak berpengaruh terhadap produksi gas CO2 maupun rasio CO2:metana pada substrat daun M.oleifera. Hal tersebut dapat disebabkan oleh belum munculnya pengaruh tanin dalam mereduksi produksi gas metana/DBO. Kemungkinan ini dapat dijelaskan oleh pernyataan Jayanegara et al. (2009b) berupa kurangnya konsentrasi tanin yang ditambahkan dalam substrat atau tanin yang digunakan dalam penelitian belum melalui proses purifikasi. Kedua kemungkinan tersebut menggambarkan tanin yang digunakan belum mencapai limit konsentrasi yang dibutuhkan untuk meningkatkan efisiensi pakan berupa penurunan gas metana. Hasil yang berbeda dilaporkan oleh Sasongko et al. (2016) di mana dalam dosis yang sama dengan penelitian ini, penambahan tepung daun nangka dapat menurunkan produksi gas metana dan meningkatkan rasio $\mathrm{CO}_{2}$ :metana pada substrat kacang hijau afkir. Perbedaan ini diduga disebabkan oleh perbedaan karakter serat substrat pakan, dimana tanin lebih mudah mereduksi gas metana pada pakan biji-bijian yang mengandung serat kasar rendah.

\section{Karakteristik produk fermentasi rumen}

Peubah hasil fermentasi rumen berupa $\mathrm{pH}, \mathrm{NH}_{3}$, VFA total, populasi protozoa dan DBO dapat dilihat pada Tabel 3. Penambahan tepung daun nangka tidak berpengaruh terhadap konsentrasi $\mathrm{NH}_{3}$ pada kedua hijauan pakan. Penambahan tepung daun nangka tidak berpengaruh terhadap nilai $\mathrm{pH}$ substrat jerami V.radiata. Hal berbeda ditunjukkan pada pemberian 1,4\% tepung daun nangka pada substrat daun $M$. oleifera yang dapat meningkatkan nilai $\mathrm{pH}$ sebesar 6\% $(P<0,05)$. Penambahan tepung daun nangka juga tidak berpengaruh 
terhadap produksi VFA total jerami $V$. radiata, sedangkan produksi VFA total substrat daun M.oleifera dapat menurun $32,11 \%$ akibat penambahan tepung daun nangka pada taraf $0,7 \% \quad(P<0,05)$. Pada peubah populasi protozoa, penambahan tepung daun nangka dapat menurunkan populasi protozoa pada kedua substrat hijauan pakan $(P<0,05)$. Penambahan $0,7 \%$ tepung daun nangka juga dapat meningkatkan DBO sebesar 4,46\% (V. radiata) dan $3,73 \%$ ( $M$. oleifera) $(P<0,05)$, sedangkan penambahan tepung daun nangka pada taraf $1,4 \%$ tidak berpengaruh terhadap nilai DBO.

Nilai pH keenaam perlakuan pada kondisi optimal untuk proses fermentasi dalam rumen yaitu $>6,00$. Mould et al. (1984) menjelaskan bahwa proses pencernaan selulosa dalam rumen oleh mikroba akan terhambat pada kondisi $\mathrm{pH}<6,00$. Hal tersebut membuktikan bahwa penambahan tepung daun nangka tidak mengganggu proses degradasi pakan secara keseluruhan. Proses degradasi pakan yang tidak terganggu dibuktikan pada nilai peubah DBO yang justru meningkat pada penambahan $0,7 \%$ tepung daun nangka. Penambahan tepung daun nangka hanya berdampak pada populasi protozoa yang bersimbiosis langsung dengan bakteri metanogen. Populasi protozoa yang berkurang akan memberikan kesempatan pada bakteri selulolitik untuk berkembang. Konsentrasi $\mathrm{NH}_{3}$ ketiga perlakuan juga dalam kondisi optimal untuk sistem fermentasi in vitro secara tertutup. Wanapat et al. (2013) melaporkan bahwa konsentrasi $\mathrm{NH}_{3}$ yang optimal untuk proses fermentasi pada sistem kultur in vitro secara tertutup adalah 5 $\mathrm{mg} / 100 \mathrm{ml}$, namun tergantung pada laju fermentabilitas substrat pakan. Konsentrasi $\mathrm{NH}_{3}$ pada ketiga perlakuan substrat daun $M$. oleifera sedikit lebih tinggi dibandingkan perlakuan jerami $V$. radiata. Hal tersebut disebabkan oleh kandungan PK pakan daun $M$. oleifera yang lebih tinggi. $\mathrm{NH}_{3}$ merupakan representasi degradasi protein oleh mikroba rumen menjadi asam amino yang kemudian mengalami deaminasi dan menjadi $\mathrm{NH}_{3}$ sebagai komponen penting sintesis protein mikroba.

Perubahan produksi VFA total hanya terjadi pada substrat pakan daun $M$. oleifera yang ditambahkan $0,7 \%$ tepung daun nangka. Penurunan produksi VFA total dapat disebabkan oleh proses inhibisi pencernaan serat oleh tanin yang terkandung dalam tepung daun nangka. Produksi VFA total yang menurun merupakan refleksi dari perubahan populasi mikroba rumen. ElWaziry et al. (2007) melaporkan bahwa penambahan $0,5 \mathrm{mg} / \mathrm{ml}$ tanin murni ke dalam substrat pakan jerami dapat menurunkan produksi VFA total sebesar 5,7-11,7\%. Namun demikian, penurunan produksi VFA total ternyata tidak berpengaruh terhadap peubah DBO. Penjelasan dari hal ini adalah produksi VFA yang ada masih pada taraf optimal dalam ekosistem mikroba rumen. Rumen kerbau yang diberi pakan jerami padi, jerami padi fermentasi dan konsentrat menghasilkan produksi VFA total berturutturut 44,8; 48,9 dan 55,9 mM (Chanthakhoun dan Wanapat 2012). Penurunan populasi protozoa akibat penambahan tepung daun nangka dapat disebabkan oleh adanya senyawa tanin dapat menurunkan populasi aktor utama dalam proses metanogenesis di dalam rumen yaitu protozoa (Animut et al., 2008). Hal tersebut berdampak pada populasi bakteri metanogen yang

Tabel 3. Karakteristik produk fermentasi rumen secara in vitro pada jerami $V$. radiata dan daun $M$. oleifera yang ditambahkan tepung daun nangka

(characteristics of in vitro rumen fermentation product on V. radiata straws and M. oleifera leaves with jackfruit leave addition)

\begin{tabular}{ccccccc}
\hline \hline $\begin{array}{c}\text { Sampel } \\
\text { (sample) }\end{array}$ & $\begin{array}{c}\text { Tepung daun nangka (\%) } \\
\text { (Jackfruit leaves meal (\%)) }\end{array}$ & $\mathrm{pH}$ & $\begin{array}{c}\mathrm{NH}_{3} \\
(\mathrm{mg} / 100 \mathrm{ml})\end{array}$ & $\begin{array}{c}\mathrm{VFA} \text { total } \\
(\mathrm{mM})\end{array}$ & $\begin{array}{c}\text { Protozoa } \\
\left(\times 10^{6} \mathrm{sel} / \mathrm{ml}\right)\end{array}$ & $\begin{array}{c}\mathrm{DBO} \\
(\%)\end{array}$ \\
\hline V. radiata & 0 & $6,70^{\mathrm{a}}$ & 4,93 & $74,25^{\mathrm{ab}}$ & $2,5^{\mathrm{b}}$ & $86,97^{\mathrm{b}}$ \\
V. radiata & 0,7 & $6,70^{\mathrm{a}}$ & 5,16 & $85,80^{\mathrm{ab}}$ & $1,7^{\mathrm{c}}$ & $90,85^{\mathrm{a}}$ \\
V. radiata & 1,4 & $6,50^{\mathrm{ab}}$ & 5,61 & $80,52^{\mathrm{ab}}$ & $2,2^{\mathrm{bc}}$ & $88,23^{\mathrm{b}}$ \\
M. oleifera & 0 & $6,33^{\mathrm{b}}$ & 6,12 & $92,40^{\mathrm{a}}$ & $3,7^{\mathrm{a}}$ & $74,50^{\mathrm{d}}$ \\
M. oleifera & 0,7 & $6,49^{\mathrm{ab}}$ & 6,46 & $64,02^{\mathrm{b}}$ & $2,2^{\mathrm{bc}}$ & $77,28^{\mathrm{c}}$ \\
M. oleifera & 1,4 & $6,71^{\mathrm{a}}$ & 6,63 & $77,88^{\mathrm{ab}}$ & $1,8^{\mathrm{bc}}$ & $76,45^{\mathrm{cd}}$ \\
SEM & & 0,061 & 0,093 & 3,027 & 0,026 & 1,383 \\
\hline
\end{tabular}

$\mathrm{NH}_{3}$ : konsentrasi ammonia (ammonia concentration); VFA: volatile fatty acid; DBO: degradasi bahan organik (organic matter degradability); SEM: standard error mean.

a,b,c,d Superskrip yang berbeda pada baris yang sama menunjukkan perbedaan yang nyata $(P<0,05)($ different supercsripts at the same row indicate significant differences $(P<0.05))$. 
bersimbiosis dengan protozoa. Representasi dari mekanisme tersebut dapat dilihat pada penurunan konsentrasi gas metana (\%) substrat daun $M$. oleifera serta kenaikan efisiensi pakan (rasio $\mathrm{CO}_{2}: \mathrm{CH}_{4}$ ) pada substrat jerami V. radiata. Populasi protozoa yang menurun memiliki relasi dekat terhadap emisi metana (Sofyan et al., 2015).

\section{Kesimpulan}

Penambahan tepung daun nangka tidak berpengaruh terhadap produksi gas total, produksi gas maksimum dan laju degradasi substrat pakan jerami $V$. radiata serta daun $M$. oleifera. Produksi gas maksimum dan laju degradasi jerami $V$. radiata lebih tinggi dibandingkan daun $M$. oleifera. Hal tersebut dapat disebabkan oleh perbedaan karakter serat yang mempengaruhi kecepatan degradasi. Penambahan 0,7 dan $1,4 \%$ tepung daun nangka dapat menurunkan konsentrasi gas metana substrat daun $M$. oleifera berturut turut sebesar $4,93 \%$ dan $3,19 \%$. Pada taraf pemberian yang sama, tepung daun nangka juga mampu meningkatkan rasio $\mathrm{CO}_{2}: \mathrm{CH}_{4}$ substrat jerami $V$. radiata masing-masing sebesar 4,42 dan 6,49\%. Tepung daun nangka juga tidak memberikan efek negatif terhadap performa produk fermentasi rumen $\left(\mathrm{pH}, \mathrm{NH}_{3}\right.$, VFA total dan DBO).

\section{Ucapan terima kasih}

Penulis mengucapkan terima kasih kepada Ir. Suharyono, M.Rur.Sci, Dr. Irawan Sugoro, Ir. Firsoni, MP, Shintia Nugrahini Wahyu Hardani, AMd dan seluruh staf Laboratorium Produksi Ternak. Penulis juga mengucapkan terima kasih pada bapak Dedi Ansori, saudara Khurin'in dan tenaga lapangan yang membantu kegiatan teknis penelitian .

\section{Daftar pustaka}

Ali, C. S., I. U. Din, M. Sharif, M. Nisa, A. Javaid, N. Hashmi and M. Sarwar. 2009. Supplementation of ruminally protected proteins and amino acids: feed consumption, digestion and performance of cattle and sheep. Int. J. Agric. Biol. 11: 477-482.

Animut, G., R. Puchala, A. L. Goetsch, A. K. Patra, T. Sahlu, V. H. Varel and J. Wells. 2008. Methane emission by goats consuming different sources of condensed tannins. Anim. Feed. Sci. and Technol. 144: 228-241.

AOAC. 2010. Official Methods of Analysis of AOAC International. $18^{\text {th }}$ edn. Revision 3. Association of Official Analytical Chemist, Washington DC.

Bhatta, R., M. M. Saravanan, L. Baruah and C. S. Prasad. 2015. Effect of graded level of tannin-containing tropical tree leaves on in vitro rumen fermentation, total protozoa and methane production. J Appl Microbiol. 118: 557564.

Bhatta, R., O. Enishi and M. Kurihara. 2007. Measurement of methane production from ruminants. Asian-Aust. J. Anim. Sci. 20: 1305-1318.

Blümmel, M., H. Steingass and K. Becker. 1997. The relationship between in vitro gas production, in vitro microbial biomass yield and ${ }^{15} \mathrm{~N}$ incorporated and its implication for the prediction of voluntary feed intake of roughages. $\mathrm{Br}$. J. Nutr. 77: 911-921.

Bunglavan S. J. and N. Dutta. 2013. Use of tannins as organic protectants of proteins in digestion of ruminants. J. Livest. Sci. 4: 67-77.

Chanthakhoun, V. and M. Wanapat. 2012. The in vitro gas production and ruminal fermentation of various feeds using rumen liquor from swamp buffalo and cattle. Asian J. Anim. Vet. Adv. 7: 5460.

Conway, E. J. 1950. Micro-diffusion Analysis and Volumetric Error. Lockwood. London.

Dutta, N. dan I. S. Agrawal. 2000. Effects of formaldehyde and heat treatment on protein degradability. Ind Vet J. 77: 3639.

El-Waziry, A. M., M. E. A. Nasser, S. M. A. Sallam, A. L. Abdallah and I. C. S. Bueno. 2007. Processing methods of soybean meal, 2. Effect of autoclaving and Qucbraho tannin treated soybean meal on gas production and rumen fermentation in vitro. J. Appl. Sci. 3: 17-24.

Getachew, G., H. P. S. Makkar and K. Becker. 2000. Effect of polyethilene glycol on in vitro degradability and microbial protein synthesis from tannin-rich browse and herbaceous legumes. B. J. Nutr. 84: 73-83.

Goering, H. K. and P. J. Van Soest. 1970. Forage Fibre Analysis (apparatus, reagents, procedures, and some 
application). Agric. handbook 379, ARS., USDA., Washington, DC. USA.

Hamid, P., T. Akbar, J. Hossein and M. G. Ali. 2007. Nutrient digestibility and gas production of some tropical feeds used in ruminant diets estimated by the in vivo and in vitro gas production techniques. Am. J. Anim. Vet. Sci. 2: 108-113.

Haryanto, B. 2012. Perkembangan penelitian nutrisi ruminansia. Wartazoa. 22: 169177.

Jayanegara, A. and A. Sofyan. 2008. Penentuan aktivitas biologis tanin beberapa hijauan secara in vitro menggunakan "Hohenheim gas test" dengan polietilen glikol sebagai determinan. Media Peternakan 31: 4452.

Jayanegara, A. A. Sofyan, H. P. S. Makkar and K. Becker. 2009b. Kinetika produksi gas, kecernaan bahan organic dan produksi gas metana in vitro pada hay dan jerami yang disuplementasi hijauan mengandung tanin. Media Peternakan 32: 120-129.

Jayanegara, A., G. Goel, H. P. S. Makkar and K. Becker. 2015. Divergence between purified hydrolysable and condensed tannin effects on methane emission, rumen fermentation and microbial population in vitro. Anim Feed Sci Tech. 209: 60-68.

Jayanegara, A., H. P. S. Makkar and K. Becker. 2009a. Emisi metana dan fermentasi rumen in vitro ransum hay yang mengandung tanin murni pada konsentrasi rendah. Media Peternakan 32: 185-195.

Kholif, A. E., G. A. Gouda, T. A. Morsy, A. Z. M. Salem, S. Lopez and A. M. Kholif. 2015. Moringa oleifera leaf meal as a protein source in lactating goat's diets: feed intake, digestibility, ruminal fermentation, milk yield and composition, and it's fatty acids profile. Small ruminant Res. 129: 129-137.

Kongmanila, D. and I. Ledin. 2009. Chemical composition of some tropical foliage species and their intake and digestibility by goats. Asian-Aust $\mathrm{J}$ Anim Sci. 22: 803-811.

Makkar, H. P. S. and K. Becker. 1996. Nutritional value and antinutritional components of whole and ethanol extracted Moringa oleifera leaves. Anim. Feed Sci. Technol. 63: 211-228.
Menke, K. H., L. Raab, A. Salewski, H. Steingass, D. Fritz and W. Schneider. 1979. The estimation of the digestibility and metabolizable energy content of ruminant feeding stuffs from the gas production when they are incubated with rumen liquor. J. Agric. Sci. 93: 217-222.

Mould, F. L., F. R. Orskov and S. O. Mann. 1984. Associative effects of mixed feeds. I. Effects of type and level of supplementation and the influence of the rumen fluid $\mathrm{pH}$ on cellulolysis in vivo and dry matter digestion of various roughage. Anim. Feed Sci. Technol. 10: 15.

Ogimoto, K. and S. Imai. 1981. Atlas of Rumen Microbiology. Japan Scientific Societies Press, Tokyo.

Ørskov, E. R. and I. Mcdonald. 1979. The estimation of protein degradability in the rumen from incubation measurements weighted according to the rate of passage. J. Agric. Sci. Camb 92: 499-503.

Pomolango, R., Ch. L. Kaunang dan F. H. Elly. 2016. Analisis Produksi Limbah Tanaman Pangan Sebagai Pakan Ternak Sapi di Kabupaten Bolang Mongondow Utara. Jurnal Zootek 36: 302-311.

Samadi, Y. Usman dan M. Delima. 2010. Kajian Potensi Limbah Pertanian Sebagai Pakan Ternak Ruminansia di Kabupaten Aceh Besar. Agripet 10: 45-53.

Sasongko, W. T., Khurin'in and T. Wahyono. 2016. Total gas and methane evaluation of rejected mungbean meal (Vigna radiata) with jackfruit leaves addition. Proceeding of International Seminar on Livestock Production and Veterinary Technology. (in press).

Sasongko, W. T., L. M. Yusiati, Z. Bachruddin, dan Mugiono. 2010. Optimalisasi Pengikatan Tanin Daun Nangka dengan Protein Bovine Serum Albumin. Buletin Peternakan 34: 154158.

Serensinhe, T., S. A. C. Madushika, Y. Serensinhe, P. K. Lal and E. R. Ørskov. 2012. Effects of tropical tannin non legume and low tannin legume browse mixtures on fermentation parameters and methanogenesis using gas production technique. Asian-Aust J Anim Sci. 25: 1404-1410. 
Sofyan, A., A. A. Sakti, M. F. Karimy, H. Julendra, L. Istiqomah, H. Herdian, E. Damayanti, and A. E. Suryani. 2015. Effectivity of probiotic, micromineral enriched yeast and their combination with Azadirachta indica leaves containing tannin on fermentability and digestibility of Pennisetum hybrid. JITV. 20: 95-104.

Soliva, C. R., M. Kreuzer, N. Foidl, G. Foidl, A. Machmüller and H. D. Hess. 2005. Feeding value of whole and extracted Moringa oleifera leaves forruminants and their effects on ruminal fermentation in vitro. Anim. Feed Sci. Technol. 118: 47-62.

Steel, R. G. D. and J. H. Torrie. 1980. Principles and Procedures of Statistics, $2^{\text {nd }}$ ed., McGraw-Hill., New York.

Sudrajad, P. dan Sarjana. 2011. Pemaanfaatan Brangkasan Kacang Hijau sebagai Pakan Alternatif Kambing dan Domba Saat Musim Penghujan di Grobogan. Prosiding Semiloka Nasional Dukungan AgroInovasi untuk Pemberdayaan Petani. 14 Juli 2011. Semarang, Jawa Tengah.

Suharyono dan Y. Widiawati. 2007. Ekosistem rumen sapi PO yang diberi pakan suplemen multi-nutrien (SPM) atau legor. Seminar Nasional Teknologi Peternakan dan Veteriner. 71-76.

Suprapto H., F. M. Suhartati dan T. Widiyastuti. 2013. Kecernaan serat kasar dan lemak kasar complete feed limbah rami dengan sumber protein berbeda pada kambing peranakan etawa lepas sapih. Jurnal IImiah Peternakan 1: 938-946.

Wahyuni, I. M. D., A. Muktiani dan M. Christiyanto. 2014. Kecernaan bahan kering dan bahan organik dan degradabilitas serat pada pakan yang disuplementasi tannin dan saponin. Agripet 2: 115-125.

Wanapat, M., S. Kang and K. Phesatcha. 2013. Enhancing buffalo production efficiency through rumen manipulation and nutrition. Buffalo Bull. 32 (1): 258275.

Widiawati, Y., M. Winugroho, dan P. Mahyuddin. 2010. Estimasi produksi gas metana dari rumput dan tanaman leguminosa yang diukur secara in vitro. Prosiding seminar nasional teknologi peternakan dan veteriner 3-4 Agustus 2010. Bogor: 131-136. 